\title{
Nuorten porojen painon ja ruhon koostumuksen vaihtelusta talvikautena
}

\author{
MIKKo VARo \\ Helsingin Yliopisto, kotieläinten jalostustieteen laitos
}

\section{Variation in the weight and composition of carcass of young reindeer during winter}

\author{
Mikкo Varo \\ University of Helsinki, Department of Animal Breeding
}

\begin{abstract}
The carcasses of altogether 32 reindeer aged six months and eighteen months collected from different slaughters, were cut up and analysed to find out the influence of the date of slaughter on the quality of carcass. There were generally significant decreases in the live and carcass weights and in the weights of different tissues especially in late winter. The proportions of the tissues changed significantly. The most distinct and significant changes were found in the composition of meat: as the water content increased, the fat, protein and ash contents decreased.
\end{abstract}

\section{Johdanto}

Poro on sopeutunut elämään olosuhteissa, joissa ravinnon saanti vaihtelee jyrkästi eri vuodenaikoina. Lyhyt kesä on yltäkylläisyyden aikaa, jolloin ravintoa riittää paitsi talven aikana heikentyneen kunnon kohentamiseen, myös kasvuun ja vararavinnon keräämiseen. DRURI ja Mrtuschev (1963) mainitsevat, että täysikasvuisen ja hyväkuntoisen poron ihonalaisen rasvakerroksen paksuus voi syksyllä olla jopa $8-9 \mathrm{~cm}$. Talven niukoissa oloissa rasvavarasto hupenee, mikä ilmenee myös painon voimakkaana pienenemisenä. Oheinen piirros havainnollistaa vuodenaikojen säätelemän painonkehityksen jaksollisuutta.

Käyristä nähdään, että erityisesti kevättalvi koettelee eläinten kuntoa. Myös meidän omat koetuloksemme (VARO 1972) osoittavat kasvun rajoittuvan kesäkauteen ja talven merkitsevän painonkehityksen pysähtymistä tai taantu- 


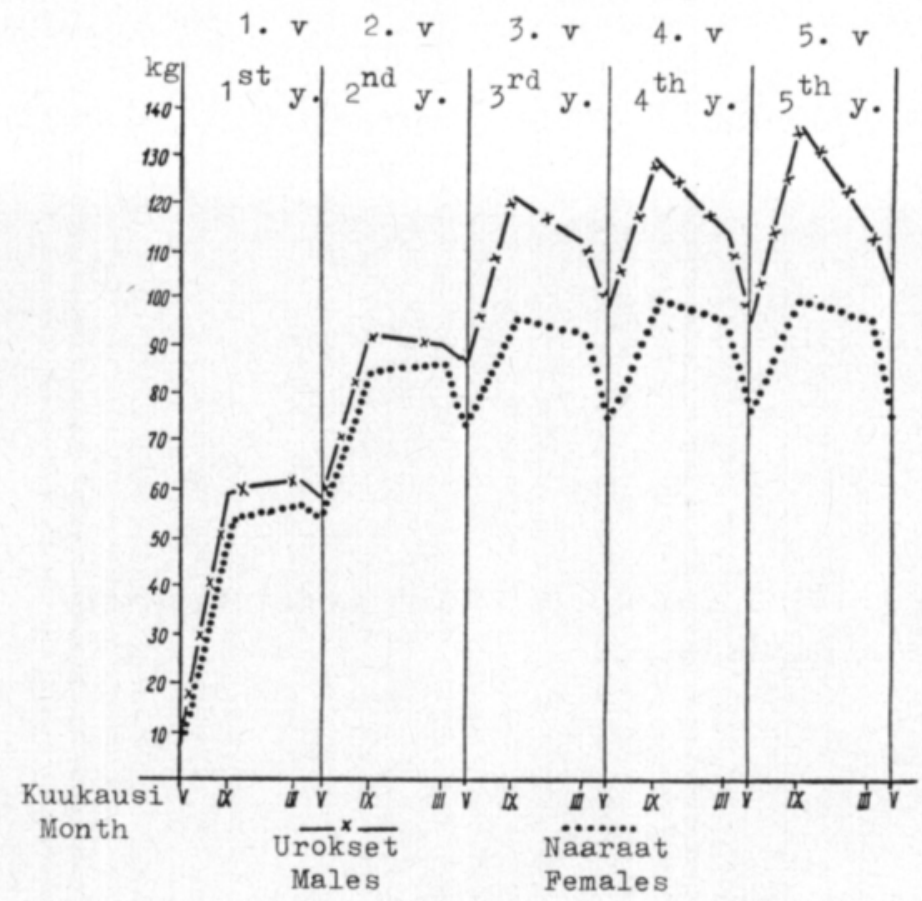

Piirros 1. Porojen painon kehitys (DRURI ja MITUSCHEV 1963). Figure 1. The development of the weights of reindeers (DRURI and MITUSCHEV 1963.)

mista. Kolmen ensimmäisen elinvuoden aikana olivat syys- ja kevätpainojen keskiarvot:

\begin{tabular}{|c|c|c|c|}
\hline & & Naaraat & Urokset \\
\hline Kevät 1963 , & syntymäpaino .... & $5.7 \mathrm{~kg}$ & $6.0 \mathrm{~kg}$ \\
\hline Syksy 1963 & .... & 40.5 & 45.5 \\
\hline Kevät 1964 & & 40.5 & 46.1 \\
\hline Syksy 1964 & ...... & 57.9 & 70.3 \\
\hline Kevät 1965 & ......... & 59.0 & 66.7 \\
\hline Syksy 1965 & ..... & $59 \cdot 9$ & 84.0 \\
\hline Kevät 1966 & ....... & 61.7 & 81.1 \\
\hline
\end{tabular}

Näin voimakas ympäristön vaikutus eläinten kasvuun ja kuntoon vaikeuttaa eri tutkimusaineistoista mitattujen lihantuotanto-ominaisuuksien vertailua. Helpompaa on vertailla ruhon eri kudososien suhteita ja lihan ravintoainekoostumusta, joskin ulkonaisten olosuhteiden ja mittausajan eroista johtuva virhemuuntelu aiheuttaa häiriöitä näissäkin. Kasvun ja ravitsemustilan kehityksen rytmi vaihtelee ajallisesti eri alueilla ja leveysasteilla, joten täsmällisten ja täysin vertailukelpoisten tietojen saaminen on lähes mahdotonta. Paikallisten eläinkantojen geneettiset erot voivat niin ikään lisätä tulosten vaihtelua.

MuhAtschev (1971) on esittänyt monipuolista tietoa eri-ikäisten tundraporojen teurasarvosta. Tässä rajoitutaan lähinnä sellaisten tulosten tarkasteluun, joilla on välitöntä mielenkiintoa omien tutkimusten kannalta. Ruhon eri 
kudososien osuudet puolen ja puolentoista vuoden ikäisillä eläimillä olivat Muhatschevin mukaan:

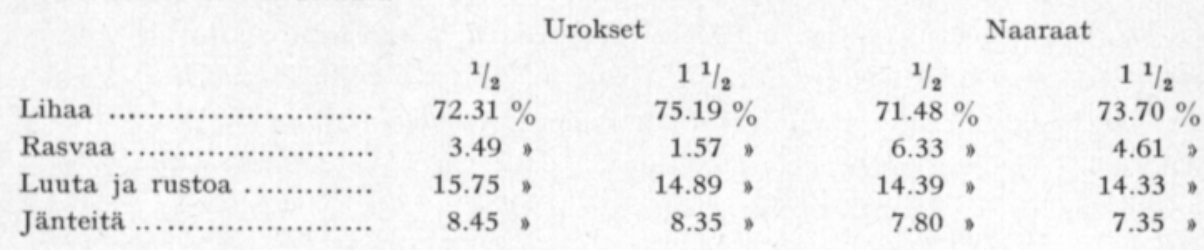

Koska rasva on yleisesti määrältään vaihtelevin ruhojen kudososa, on täydennyksenä syytä mainita, että sen osuus vastasyntyneillä uroksilla oli vain 0.94 ja naarailla $0.82 \%$. Sen sijaan 5.5-vuotiailla määrät olivat uroksilla 7.52 ja naarailla $8.06 \%$. Rasvan suhteellinen osuus näyttää siis lisääntyvän iän mukana, joskaan ei välttämättä suoraviivaisesti.

Täysikasvuisen poron lihan koostumus on Muhatschevin mukaan:

\begin{tabular}{|c|c|}
\hline 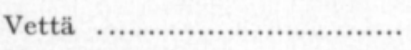 & $68.93 \%$ \\
\hline Valkuaisaineita ..................... & 18.40, \\
\hline 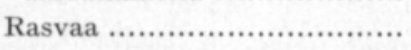 & 11.03 \\
\hline Uuteaineita ........................... & 0.64 \\
\hline 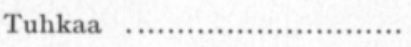 & 1.00 \\
\hline
\end{tabular}

Razanovskomn (ref. Druri ja Mituschev 1963) on esittänyt vastaavat tiedot häristä ja 5 kuukauden ikäisistä vasoista. Niiden lihan koostumus on:

\begin{tabular}{|c|c|c|}
\hline & Härät & Vasat \\
\hline Vettä $\ldots \ldots \ldots \ldots \ldots$ & $63.7 \%$ & $70.8 \%$ \\
\hline Valkuaisaineita .................. & 18.6 & 21.3 \\
\hline 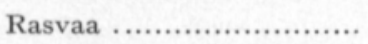 & 16.1 & 6.0 \\
\hline Hiilihydraatteja ............... & 0.6 & 0.7 , \\
\hline Tuhkaa …........................... & 1.0 & 1.2 , \\
\hline
\end{tabular}

Näitä koostumuslukuja vertailtaessa on helppo havaita, että erot pitoisuuksissa johtuvat lähes kokonaan rasvan määrän vaihtelusta. Rasvattomaksi muunnetussa lihassa olisivat vesimäärät näet $77.48,75.92$ ja $75.32 \%$, valkuaismäärät $20.68,22.17$ ja $20.66 \%$ sekä tuhkamäärät $1.12,1.19$ ja $1.28 \%$.

Omissa tutkimuksissa on pyritty selvittämään, mikä vaikutus talvikauden muuttuvilla ravitsemusolosuhteilla on nuorten porojen ruhon ja lihan koostumukseen. Valitettavasti näytteiden saanti kevättalvella osoittautui mahdottomaksi. Tutkimus on keskitetty nuoriin ikäluokkiin, koska ne sekä vasanlihan tuotannon että jalostusvalinnan kannalta ovat kiinnostavimmat. Alustava tieto talvenaikaisista muutoksista ruhon ja lihan laadussa voi antaa nykyistä paremmat edellytykset nuorten eläinten kasvatuksen ja valinnan suunnittelulle.

\section{Tutkimusaineiston hankinta}

Talvella 1969-70 kerättiin tutkimusaineistoksi vv. 1968 ja 1969 syntyneiden porojen ruhoja. Niiden tuli edustaa ikäluokkansa ja sukupuolensa keskitasoa teurastusajankohtana. Teurastukset tapahtuivat 12/11, 13/12, 5/2 ja 12/3. Kuhunkin teurastusryhmään tuli kahdeksan ruhoa, eli yhteensä 32 . 
Ruhot säilytettiin kevääseen Poro ja Riista Oy:n pakastamossa Rovaniemellä. Toukokuun lopussa ruhojen vasen puolikas leikeltiin ja lihan analysointia varten otettiin kaksi näytettä, paistista ja kaulasta, jotka lähetettiin vakuumipusseihin pakattuina hiilihappojäässä Viikkiin säilytettäväksi edelleen pakastettuina Helsingin Yliopiston elintarvikekemian ja -teknologian laitoksen varastotiloissa. Ylivoimaisten esteiden vuoksi päästiin analysointi suorittamaan vasta kesällä 1971. Paliskuntain yhdistys vastasi tutkimusaineiston hankinnasta. Sen kerääminen erotuspaikoilta ja ruhojen leikkely tapahtui yhdistyksen konsulentin, agrologi Veijo Tervosen johdolla. Analysointityön suoritti Lihateknologian laitoksella maisteri Eila Karanko Tuottajain Lihakeskuskunnan taloudellisen tuen turvin. Kaikille asianosaisille lausun vilpittömän kiitoksen.

\section{Tulokset}

Tutkimusaineistolle arvioitiin ennakolta minimikoko, joka mahdollisimman pienin uhrauksin riittäisi antamaan tyydyttävät vastaukset asetettuihin kysymyksiin. Valitettavasti varastoimisaikana katosi neljä ruhoa, jotka teurastustulosten tarkoituksenmukaista tilastollista käsittelyä varten oli korvattava lasketuilla keskiarvoluvuilla. Tämä vähensi mahdollisuutta saada aineistosta esille etsittyjä eroja ja heikensi niiden tilastollista merkitsevyyttä. Myös yksi epäonnistunut rasvanmääritys oli korvattava keskiarvolla. Analyysitulosten tilastollista merkitsevyyttä testattaessa on käytetty havaintojen todellisia lukumääriä. Aineiston puutteista huolimatta tulosten julkaisemista on uhratun työn ja rahan vuoksi pidetty aiheellisena.

Aineisto käsiteltiin ristikkäisellä varianssianalyysillä, jolla todettiin teurastusajan, iän ja sukupuolen vaikutus ruhoihin. Taulukossa 1 on esitetty luokkien keskiarvot ja niiden alapuolelle on merkitty asteriskein erojen merkitsevyydet: $*=\mathrm{P}<0.05,{ }^{* *}=\mathrm{P}<0.01$ ja ${ }^{* * *}=\mathrm{P}<0.001$.

Kolmannen eli helmikuun teurastuksen poikkeuksellista aineistoa lukuunottamatta havaitaan kaikissa keskiarvoissa melko johdonmukainen laskusuunta, jopa luissa ja jänteissä. Voimakkaaksi painojen pieneneminen näyttää muodostuvan kuitenkin vasta kevättalvella. Erikoista tuloksissa on se, että rasvan määrän väheneminen ei ole ollut tilastollisesti merkitsevä, vaikka se suhteellisesti on ollut kaikkein suurin. Selityksenä on epäilemättä se, että rasvan määrän yksilöllinen vaihtelu on ollut tavattoman suuri. Onko tähän ollut vaikuttamassa se kirjoittajan aikaisemmin (VARO 1972) viittaama mahdolliisuus, että talvikautinen painon - ja samalla ravitsemustilan - muutos saattaa perustua perittyihin yksilöllisiin kykyihin tyydyttää ravinnontarve äärimmäisen ankarissa oloissa. Kysymyksen jatkuva tutkiminen olisi erityisesti jalostusvalinnan perusteiden oikean määrittelyn kannalta tarpeellinen.

Myös ikäluokkien välillä rasvan määrässä ero on suhteellisesti suurin, mutta se ei silti ole yhtä merkitsevä kuin eräissä muissa ominaisuuksissa. Sukupuolet eroavat merkitsevästi vain luiden määrässä, mutta suhteellisesti suurin ero havaitaan rasvoittumisessa.

Taulukosta 2 nähdään teurasprosentin ja ruhon koostumuksen vaihtelu. Kudosten suhteelliset määrät muuttuvat selvästi vähemmän kuin absoluuttiset, niin että teurastuksen ajankohta ei ole ainoassakaan tapauksessa aiheut- 
Taulukko 1. Painojen keskiarvot luokittain.

Table 1. Average weights according to month of slaughter, age and sex.

\begin{tabular}{cccccccc}
\hline & & & \multicolumn{3}{c}{ Ruhon koostumus } \\
Luokitus & Elopaino & Teuraspaino & & \multicolumn{3}{c}{ Composition of carcass } \\
\cline { 4 - 7 } Classification & $\mathbf{k g}$ & $\mathbf{k g}$ & Lihaa & Rasvaa & Luuta Jänteitä \\
& Live weight & Carcass weight & $\mathbf{k g}$ & $\mathrm{g}$ & $\mathrm{kg}$ & $\mathrm{g}$ \\
& & & & Meat & Fat & Bone Ligament \\
\hline
\end{tabular}

Teurastusaika:

Month of slaughter:

\begin{tabular}{|c|c|c|c|c|c|c|c|}
\hline 11. -69 & …................ & 47.8 & 22.4 & 15.0 & 290 & 5.2 & 289 \\
\hline 12. -69 & …................ & 44.7 & 21.3 & 14.0 & 235 & 4.6 & 221 \\
\hline 2. -70 & n................... & 46.6 & 22.2 & 15.7 & 482 & 5.1 & 236 \\
\hline-70 & n................. & 40.9 & 18.7 & 12.2 & 103 & 4.1 & 149 \\
\hline
\end{tabular}

Erojen merkitsevyys ........

Significance of differences

Ikä syksyllä 1969:

Age in fall 1969:
$1 / 2$ v y. .................
$11 / 2 \mathrm{v} y$.
Erojen merkitsevyys ........
Significance of differences

36.8

17.6

24.7

11.8

128

$4.1 \quad 225$

53.2

$\begin{array}{ll}16.7 & 428\end{array}$

$5.4 \quad 222$

Sukupuoli:

Sex:

$$
\text { Uros - Male ............. }
$$

46.5

Naaras - Female ....... 43.5

21.8

14.7

13.8

187

$5.1 \quad 209$

20.5

370

$4.3 \quad 238$

Erojen merkitsevyys ........

Significance of differences

Koko aineisto

45.0

21.1

14.2

278

4.7

tanut niihin merkitseviä eroja. Tämä osoittaa, että painonmenetys kohdistuu koko elimistöön varsin tasaisesti ja saattaa merkitä, että eläin kuluttaa vararavinnokseen paitsi rasvaa myös muita kudoksia. Kuitenkaan ei voitane sulkea pois sitäkään mahdollisuutta, että parhaiten kehittyneet nuoret eläimet ovat suhteellisen runsaasti joutuneet teuraiksi jo alkutalvesta. Ikäluokkien ja sukupuolten erot ovat yleensä pienet, joskin rasvaa on vanhemmilla selvästi enemmän. Naarailla näyttää rasvaa myös olevan enemmän kuin uroksilla, mutta ero ei ole merkitsevä.

Verrattaessa lukuja edellä esitettyihin Muhatschevin ilmoittamiin koostumuslukuihin, havaitaan suuri ero luiden ja jänteiden määrissä. Koska näiden kudososien yhteismäärät näyttävät verraten yhdenmukaisilta jopa vastaavia ikäluokkia ja sukupuolia vertailtaessa, täytyy erojen syynä olla ilmeisesti luuja jännekudosten täysin erilainen erottelu. RyDBERGin (1971) koetuloksista 
Taulukko 2. Ruhon suhteellinen koostumus luokittain.

Table 2. Relative composition of carcass according to month of slaughter, age and sex.

\begin{tabular}{cccccc}
\hline & & \multicolumn{3}{c}{ Ruhon } & koostumus - Composition of carcass \\
\cline { 3 - 6 } Luokitus & Teuras- $\%$ & Lihaa & Rasvaa & Luuta & Jänteitä \\
Classification & & $\%$ & $\%$ & $\%$ & $\%$ \\
& Slaughter- $\%$ & Meat & Fat & Bone & Ligament \\
\hline
\end{tabular}

Teurastusaika:

Month of slaughter;

$\begin{array}{rrrrrrrr}11 . & -69 & \ldots \ldots \ldots \ldots \ldots \ldots & 47.0 & 72.3 & 1.4 & 24.8 & 1.5 \\ 12 . & -69 & \ldots \ldots \ldots \ldots \ldots \ldots \ldots & 48.2 & 73.4 & 1.2 & 24.2 & 1.2 \\ 2 . & -70 & \ldots \ldots \ldots \ldots \ldots \ldots \ldots & 47.7 & 73.3 & 1.8 & 23.8 & 1.1 \\ 3 . & -70 & \ldots \ldots \ldots \ldots \ldots \ldots \ldots & 45.6 & 73.6 & 0.5 & 25.0 & 0.9\end{array}$

Erojen merkitsevyys .

Significance of differences

Ikä syksyllä 1969:

Age in fall 1969:
$1 / 2$ v y.
$11 / 2$ v y.

48.0

46.3

72.8
73.6

0.6

25.2

1.4

Erojen merkitsevyys

Significance of differences

Sukupuoli:

Sex:

$$
\begin{aligned}
& \text { Uros - Male ............ } \\
& \quad \text { Naaras - Female } \ldots . . . . \\
& \text { Erojen merkitsevyys ........ } \\
& \text { Significance of differences }
\end{aligned}
$$

46.8

0.8

1.6

25.6

1.0

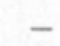

Total material

laskettavissa oleva keskimääräinen luuprosentti n. 22.8 on sen sijaan varsin lähellä meidän aineistomme tuloksia. Ääriarvot hänen aineistossaan olivat $20.2-28.8 \%$.

Jos lihaprosentit muunnetaan vastaamaan rasvatonta ruhoa, ovat puolija puolitoistavuotiaiden lihaprosentit 73.2 ja 74.9. Muhatsvchevin edellä esitetyn aineiston vastaavat luvut olisivat samoin muunnettuina 75.6 ja $\mathbf{7 6 . 8}$. Ero on samansuuntainen, mutta oman aineiston arvot jäävät jälkeen parin prosentin verran. Tämä ero saattaa johtua meidän koeaineistomme ruhojen pitkäaikaisesta säilytyksestä, joskin myös erilaiset teurastusajat voivat olla erojen aiheuttajina. Urosten ja naaraiden muunnetut lihaprosentit omassa aineistossa olivat 73.2 ja 74.9. Vastaavat luvut venäläisessä aineistossa olivat 75.7 ja 76.8, joten ero on jälleen samansuuntainen.

Rasvan määrien selvä ero suomalaisessa ja venäläisessä aineistossa johtunee pääasiassa laidunten erilaisuudesta tai erilaisesta teurastusajasta. Myös rotuerot voivat olla erojen syynä. 
Taulukko 3. Lihan koostumus luokittain.

Table 3. Composition of meat according to month of slaughter, age and sex.

\begin{tabular}{|c|c|c|c|c|}
\hline $\begin{array}{l}\text { Luokitus } \\
\text { Classification }\end{array}$ & $\begin{array}{c}\text { Vettä } \\
\% \\
\text { Water }\end{array}$ & $\begin{array}{c}\text { Rasvaa } \\
\% \\
\text { Fat }\end{array}$ & $\begin{array}{c}\text { Valkuaisaineita } \\
\% \\
\text { Protein }\end{array}$ & $\begin{array}{c}\text { Tuhkaa } \\
\% \\
\text { Ash }\end{array}$ \\
\hline \multicolumn{5}{|l|}{$\begin{array}{l}\text { Teurastusaika: } \\
\text { Month of slaughter; }\end{array}$} \\
\hline 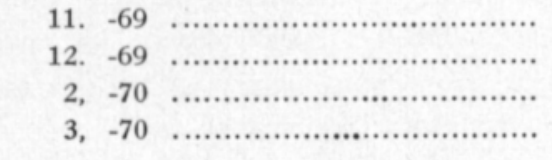 & $\begin{array}{l}73.6 \\
74.8 \\
74.9 \\
75.9\end{array}$ & $\begin{array}{l}3.2 \\
2.7 \\
2.5 \\
1.9\end{array}$ & $\begin{array}{l}21.6 \\
21.1 \\
20.9 \\
20.8\end{array}$ & $\begin{array}{l}1.02 \\
1.01 \\
1.00 \\
1.00\end{array}$ \\
\hline $\begin{array}{l}\text { Erojen merkitsevyys .......................... } \\
\text { Significance of differences }\end{array}$ & $* * *$ & $*$ & $*$ & $* *$ \\
\hline \multicolumn{5}{|l|}{$\begin{array}{l}\text { Ikä syksyllä 1969: } \\
\text { Age in fall 1969: }\end{array}$} \\
\hline 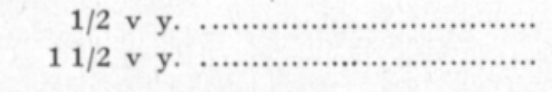 & $\begin{array}{l}75.0 \\
74.6\end{array}$ & $\begin{array}{l}2.5 \\
2.6\end{array}$ & $\begin{array}{l}20.9 \\
21.4\end{array}$ & $\begin{array}{l}1.01 \\
1.00\end{array}$ \\
\hline $\begin{array}{l}\text { Erojen merkitsevyys ........................... } \\
\text { Significance of differences }\end{array}$ & - & - & $*$ & $* *$ \\
\hline \multicolumn{5}{|l|}{$\begin{array}{l}\text { Sukupuoli: } \\
\text { Sex: }\end{array}$} \\
\hline $\begin{array}{l}\text { Uros - Male ............................... } \\
\text { Naaras - Female ......................... }\end{array}$ & $\begin{array}{l}75.1 \\
74.4\end{array}$ & $\begin{array}{l}2.2 \\
3.0\end{array}$ & $\begin{array}{l}21.2 \\
21.1\end{array}$ & $\begin{array}{l}1.01 \\
1.01\end{array}$ \\
\hline $\begin{array}{l}\text { Erojen merkitsevyys ........................... } \\
\text { Significance of differences }\end{array}$ & $*$ & $* *$ & - & - \\
\hline $\begin{array}{l}\text { Koko aineisto } \\
\text { Total material }\end{array}$ & 74.8 & 2.6 & 21.1 & 1.01 \\
\hline
\end{tabular}

Taulukossa 3 esitetyt lihan koostumustiedot osoittavat, että koostumuksen muutos talvikautena on lihassa merkitsevä. Valkuaisaineiden, rasvan ja tuhkan vähetessä vesipitoisuus suurenee. Eri ikäluokkien ja eri sukupuolten keskiarvot ovat erittäin yhdenmukaiset. Selvä ero havaitaan vain siinä, että naarailla on lihan rasvapitoisuus merkitsevästi suurempi kuin uroksilla. Muuntamalla pitoisuudet rasvatonta lihaa vastaaviksi on lihaprosentti 76.8, valkuaisprosentti 21.7 ja tuhkaprosentti 1.04. Nämä vastaavat hyvin venäläisten aineistojen vastaavia pitoisuuksia. Suurimpana erona on meidän aineistomme pieni tuhkapitoisuus.

On erikoista, että tuhkamäärien erot eri teurastuksissa ja eri ikäluokissa ovat merkitsevät, vaikka ne absoluuttisesti ovat erittäin pienet. Tilastollisesti se on selitettävissä erittäin pienellä luokkien sisäisellä muuntelulla. Toisaalta nimenomaan teurastusaikojen aiheuttamien erojen merkitsevyys voi johtua siitä, että eläimet elävät tuhka-aineisiin nähden todella nälkärajalla, jolloin minkä tahansa kivennäisaineen saannin vaikeutuessa hyvin pienetkin muutokset tuntuvat tilastollisessa tarkastelussa. 
Mainittakoon täydennyksenä, että lihan rasva-, valkuaisaine- ja tuhkapitoisuus oli paistissa hyvin $\left({ }^{* *}\right)$ tai erittäin $\left({ }^{* * *}\right)$ merkitsevästi pienempi kuin kaulassa. Koska lihanäytteet jouduttiin ottamaan pakastetuista ruhoista, oli toinen näyte käytännöllisistä syistä otettava kaulasta eikä lavasta, kuten alunperin oli suunniteltu.

Vesipitoisuuden osalta laskettiin myös yksilöiden välinen muuntelu luokkien (so. teurastusaika - ikä - sukupuoli) sisällä. Yksilölliset erot olivat merkitseviä. Teurastusaikojen väliset erot pysyivät merkitsevinä myös yksilölliseen muunteluun verrattuna. Tämä osoittaa kuiva-aineen yleistä vähenemistä, jonka merkitystä korostaa vielä se, että samanaikaisesti tapahtunut eri kudosten ja koko elimistön kuihtuminen on vähentänyt myös ravintoaineiden absoluuttimääriä.

\section{Tulosten tarkastelu}

Esillä oleva tutkimus pyrkii alun alkaenkin vain alustavan tiedon saamiseen talvikauden vaikutuksesta poron ruhoon. Odotettua suurempien häiriöiden vuoksi täsmällisten johtopäätösten teko on puutteellisesta aineistosta vaikeaa. Saadut tulokset viittaavat siihen, että talvikauden vaikutus tutkittuihin piirteisiin tuntuu voimakkaasti vasta myöhäistalvella. Näyttää ilmeiseltä, että nuoretkin porot selviytyvät ilman vaurioita syksystä ja syystalvesta,jolloin niiden valinta tuleviksi jalostuseläimiksi pyritään suorittamaan.

Laajempaa merkitystä on niillä tuloksilla, jotka osoittavat sekä elimistön eri kudosten että lihaskudoksen ravintoainepitoisuuksien vähenevän talven kuluessa. Tätä tapahtumaa voidaan tarkastella toisaalta tuotantoon liittyvänä ruokintaongelmana, koska se oikeuttaa odottamaan, että lisärehulla olisi kenties mahdollista torjua tuotannon pysähtyminen tai taantuminen taikka jopa turvata jatkuva kasvu myös talvikautena. Toisaalta asiaa voidaan tarkastella, kuten Druri ja Mituschev, poron sopeutumiskyvyn osoittajana. Sopeutuminen säännöllisesti vuorottelevaan yli- ja aliruokintaan on tehnyt porosta pohjoisten seutujen korvaamattoman hyötyeläimen. Voimakas pyrkimys poron ravinnontarpeen jatkuvaan tyydyttämiseen muunlaisin kuin porotalouden perinteellisin keinoin, saattaa helposti aiheuttaa niiden etujen vähenemisen, joita poro riistaeläimenä tarjoaa: se etsii itse ruokansa tarvitsematta hoitoa tai suojarakennuksia. Kaikkia toimenpiteitä porotalouden kehittämiseksi on sen vuoksi tarkasteltava monipuolisesti kokonaistaloudellisina kysymyksinä. Nyt saadut tulokset eivät näin ollen oikeuta pitkälle meneviin päätelmiin siitä, kuinka talven aiheuttama häiriö poron ravitsemuksessa olisi torjuttava. Epäilemättä ne kuitenkin korostavat jo nyt omaksuttua pyrkimystä ohjata porotalouden tuotanto lähinnä talvilaitumia säästävään vasanlihan tuotantoon. Tämä tavoite on sopusoinnussa myös poronjalostuksen päämäärien kanssa. Jalostusvalinta muodostuu sitä tehokkaammaksi, mitä johdonmukaisemmin vasanlihan tuotanto teurastuksineen karsii laitumia kuluttamasta kaikki muut kuin hyvin kehittyneet, terveet ja voimakkaat varsinaiset jalostuseläimet.

Myös muut porojen ravitsemustilaa kohentavat toimenpiteet ovat tarpeellisia ja puolustettavissa, kunhan ne ovat taloudellisesti toteutettavissa. Nyt saadut tulokset viittaavat myös siihen, että porojen talvirehun kivennäisva- 
jauksen korvaaminen on eräs tärkeistä ravitsemusongelmista. Vaikka jäkälillä on poikkeuksellinen kyky koota valikoivasti suuria määriä kivennäisaineita köyhältä kasvualustalta (HALE 1970), on poron tärkeimpien rehujäkälien sisältämä tuhkamäärä samoin kuin eri kivennäisaineiden määrät erikseen varsin pieniä (Poijärvi 1945, Druri ja Matuschev 1963). Siitä johtuu, että paitsi typen, myös kalsiumin ja fosforin tase on jäkäläruokinnassa negatiivinen. Oman tutkimuksen osoittama lihan talvenaikainen valkuais- ja tuhkakato saa tästä selityksensä. DJATSENkon (1971) mukaan ureakivennäislisäruokintakokeet Neuvostoliitossa ovat osoittaneet tällaisen lisäruokinnan taloudellisesti kannattavaksi ja eläintappioita vähentäväksi. Myös RyDBERG (1971) pitää puutetilojen torjumista lisäruokinnalla tärkeänä, vaikka korostaakin erityisesti, että täydellinen ruokinta lisärehuilla ei ole kannattavaa.

Porotalouden monitahoisten ongelmien ratkaiseminen näyttää tältä taustalta tarkasteluna edellyttävän soveltavia tieteitä monipuolisesti edustavan työryhmän perustamista ohjaamaan porotalouden tuottavuuden parantamiseen pyrkivää tutkimusta.

\section{KIRJALLISUUS}

Djatschenкo, N. O. 1971. Primenenie karbamidnomineralnoj prodkormki v severnom olenevodstve. Lyhennelmä: Urea-kivennäislisäruokinnan käyttö poronhoidossa. Porosymposiumi Rovaniemellä 26-27. 5. 1971, 123-141. Maa- ja metsätalousministeriö. Helsinki.

Druri, I. V. \& Mrtuschev, P. V. 1963. Olenovodstvo, 243 s. Moskova i Leningrad.

Hale, M. E. Jr. 1970. The Biology of Lichens, 176 s. Edward Arnold Ltd. London.

Muнatschev, A. D. 1971. Mjasnaja prduktivnost severnyh olenej. Lyhennelmä: Porojen lihantuotannosta. Porosymposiumi Rovaniemella 26-27.5.1971, 197-206. Maaja metsätalousministeriö. Helsinki-

PoIJäRVI, I. 1945. Jäkäläruokinnalla olevien porojen jäkälänkulutus syksystä kevääseen. Valt. Maatal. koet. Tied. 205.

RYDBERG, A. 1971. Tillskottsutfodring till renar. Porosymposiumi Rovaniemellä 26-27.5. 1971, p. 175-188. Maa- ja metsätalousministeriö. Helsinki.

VARo, M. 1972. Investigations on the possibilities of reinder breeding II. J. Scient. Agric. Soc. Finl. 44: 234-248. 